\title{
Study of Preservation Status and Dietary Reconstruction in the Human Remains Recovered from Roopkund Lake through Chemical Analysis of Faunal Remains
}

\author{
Yogambar Singh Farswan ${ }^{1 *}$ and Jaibir Singh ${ }^{2}$ \\ 1. Department of History \& Archaeology, H.N. Bahuguna Garhwal University, Garhwal-246174, India \\ 2. Department of History, Bal Ganga Maha Vidhyala, Sendul, Garhwal-246174, India
}

\begin{abstract}
Present study is carried out in the bone samples collected from Roopkund Lake in district Chamoli Garhwal, Uttarakhand which is located at 5,029 meters from main sea level in between Nanda Ghunghti and Trishuli peak. This historical site belongs to 9th century A.D. All the samples selected for the study were dried in room temperature as well as hot air oven at $32{ }^{\circ} \mathrm{C}$. Cleaning, pretreatment and digestion process of faunal remains was followed through established scientific methods. Chemical analysis i.e. concentration of different elements such as calcium, strontium, barium, magnesium and zinc as well as isotopic ratios of Carbon and Nitrogen was estimated with the help of ICP (inductively coupled plasma spectroscopy) and AAS (atomic absorption spectrophotometer). The results obtained from the chemical analysis are significant. On the basis of concentration of different elements and ratios of Nitrogen and Carbon isotopes, the dietary habits of the peoples buried in the Roopkund Lake are identified, which is different from sample to sample person to person. Besides this, the results are also significantly helpful for knowing the preservation status of faunal remains in Roopkund Lake. Finally this study also indicated the potentiality of chemical analysis for reconstructing the palaeodiet behaviour and preservation status of bone remains.
\end{abstract}

Key words: Roopkund Lake, dietary reconstruction, chemical analysis, faunal remains, archaeological site.

\section{Introduction}

This paper reports a general investigation into the status of preservation, degree and nature of post depositional changes as well as dietary reconstruction in the human bones recovered from Roopkund Lake of Garhwal Himalaya. It has been well established that bones are a rich source of information at an archaeological site [1], as they are used to get the information about the fauna of the site and also to assess various aspects of behavioral activities of humans and carnivores [2-5].

Meanwhile, it has also been worked out that dietary reconstruction through chemical analysis of bones is an important aspect of archaeological research. A number of studies on palaeodietary reconstruction have been carried out by various workers on the

"Corresponding author: Yogambar Singh Farswan, Associate Professor, research field: environmental archaeology. E-mail: farswanys@yahoo.co.in. faunal remains recovered from various archaeological sites of the world [6-15]. The analytical methods used in dietary reconstruction were estimation of trace element contents and isotopic ratios of Carbon and Nitrogen in the faunal remains excavated from different archaeological sites, as these both methods are found to be potentially significant for reconstructing the diet of ancient human population.

Present study is mainly considered keeping in view of the potentiality of estimation of Carbon \& Nitrogen isotope ratios and trace element analysis in archaeological faunal remains as well as importance of state of preservation and palaeodietary reconstruction in the faunal remains of buried peoples from Roopkund Lake.

Before going through materials and methods it is also equally important to discuss about the history of buried human remains of mysterious Lake of Roopkund, which is situated at an altitude of 5,029 
meters (around 16,750 feet) from main sea level in the interior of district Chamoli, Uttarakhand (Figs. 1, 2 and 3) India. The Lake is rather shallow having a depth of $2 \mathrm{~m}$ with the edges covered with snow for most part of the year. In summer season when the snow melts, the human remains can see, some of them are still having the flesh. These remains are preserved in the alpine conditions for the centuries.

It is believed that these are the remains of about 300-500 persons and as per the radiocarbon dating, estimated by Oxford University it is clear that these persons were died around 9th Century A.D. But it is still a mystery about the origin of these peoples. However, the legendary history of Garhwal Himalayan region indicates that these persons were related to the legend of Nanda Devi Raj Jat. Because it is an important and existing event from the spirituous and cultural point of view, as the shrines of Nanda Devi are scattered all over the Central Himalayas. This spiritual and religious event is organized in every 12 years.

Therefore, keeping in view of the earlier work as well as significance of bone remains recovered from Roopkund, present investigation i.e. study of preservation status and dietary reconstruction in faunal remains of Roopkund through elemental analysis and estimation of isotopic ratios of Carbon and Nitrogen was carried out to fulfill the aim of the research.

For the purpose of chemical analysis all the basic treatment of faunal remains was done in our laboratory, while the elemental analysis and estimation of isotopic ratios has been done with the help of Laboratory for archaeological science, Wisconsin University, Madison, Wisconsin, USA.

\section{Materials and Methods}

Materials and methods include collection and selection of bone samples, cleaning, pretreatment, elemental analysis, estimation of isotopic ratios and hydrogen ion concentration.

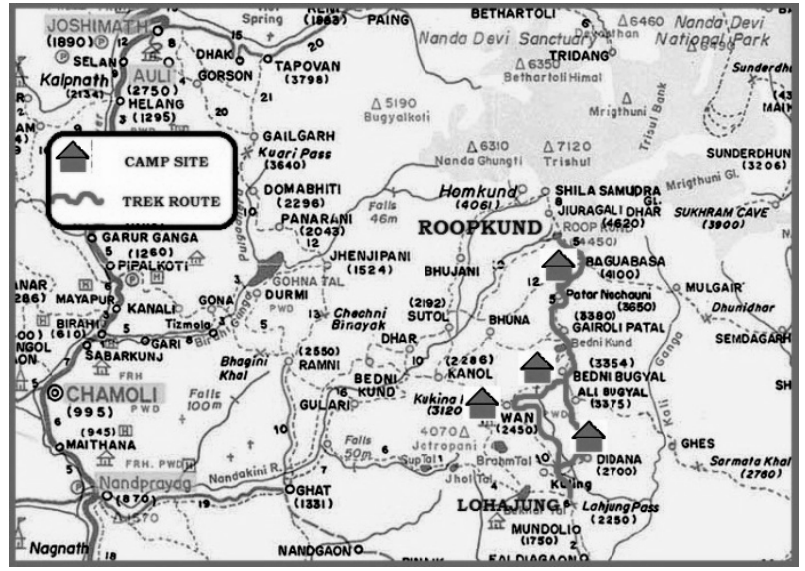

Fig. 1 Map of the location of the site.

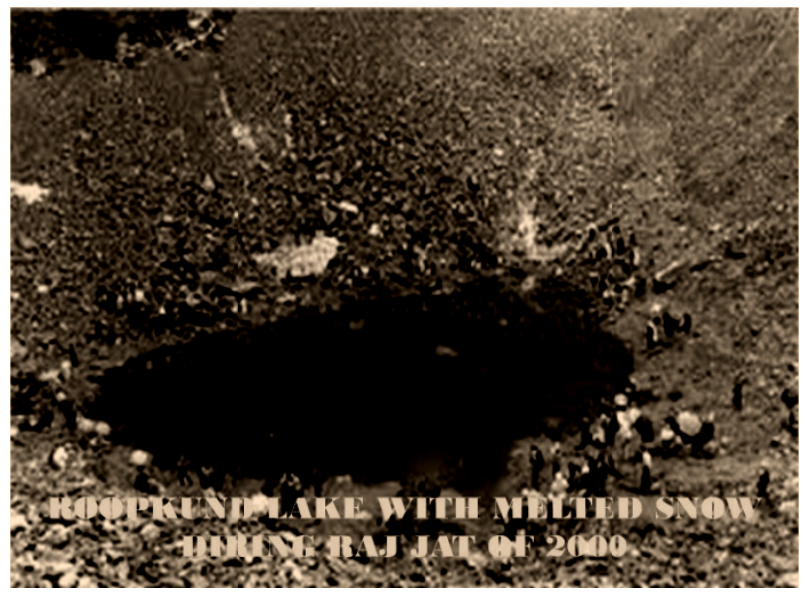

Fig. 2 Roopkund Lake in summer.

For the present study a total of 20 faunal remains of long bones (Figs. 4 and 5) were collected from different locations and depths of Roopkund Lake during the summer season of 2005 (Figs. 1, 2 and 3). The collected samples were cleaned and pretreated in laboratory by using different mechanical and chemical techniques. All the flesh, tendon, cartilage, and any other non-bone tissue were removed from each bone samples by scraping with the edge of glass.

The entire bone samples were broken to expose the medullar cavity and the exposed surfaces were then abraded with Moto tool to remove contamination, such as, dust particles, calcification and other type of external deposition. Besides this the outermost layer of all bone samples were also removed, since this part contains most of the digenetic contamination. For the betterment of chemical analysis it is necessary 

Roopkund Lake through Chemical Analysis of Faunal Remains

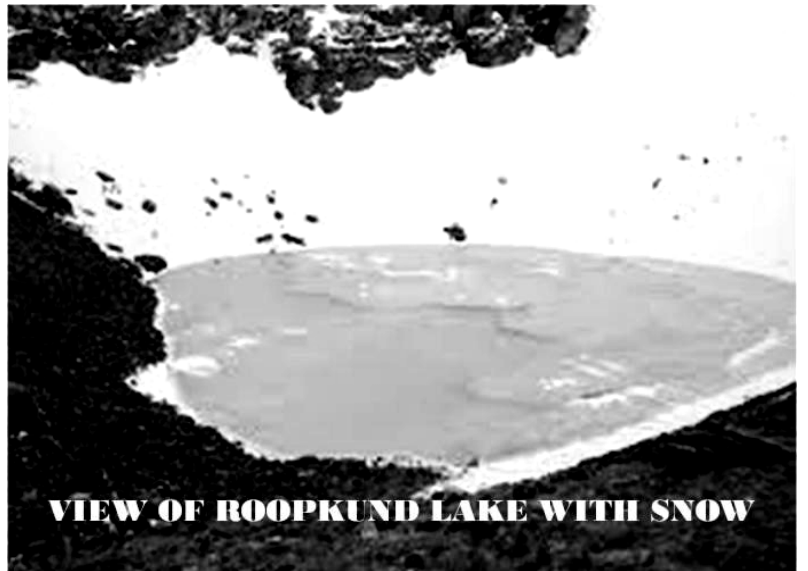

Fig. 3 Roopkund Lake in winter.

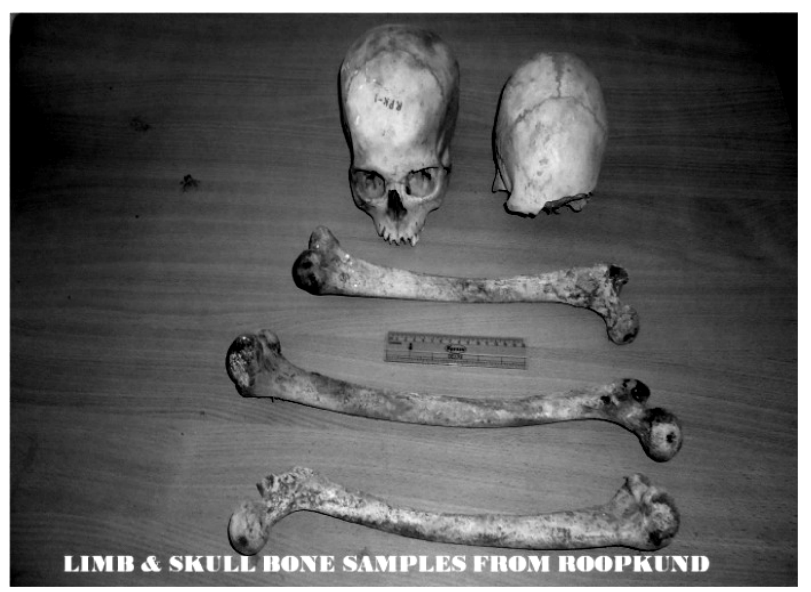

Fig. 4 Human skull \&limb bones.

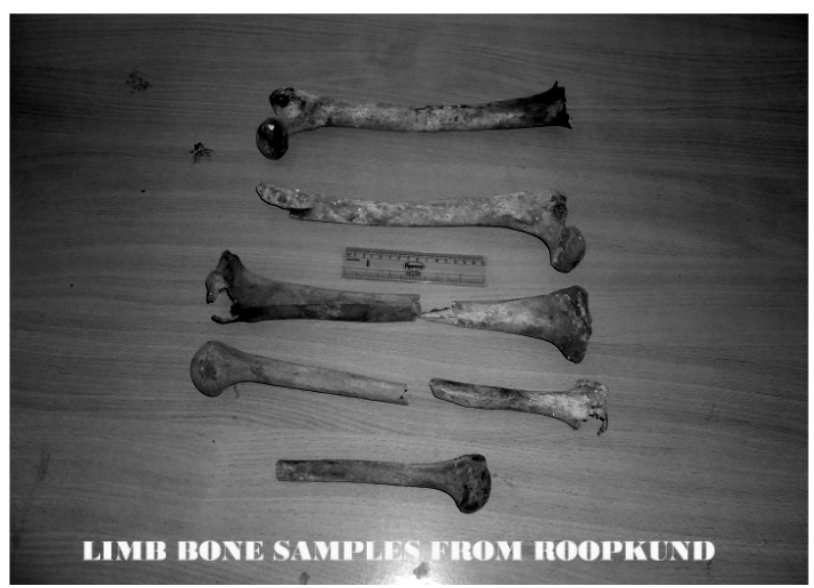

Fig. 5 Human limb bones.

to select the shaft of long bones i.e. femur or humorous.

For the purpose of elemental analysis, abraded pieces of bones were broken into small pieces and cleaned with aid of ultrasonic bath, allowed to acid wash in 1-Molar or 1-Normal acetic acid solution for overnight, ringed in de-ionized water and dried at $80-90{ }^{\circ} \mathrm{C}$ for a few hours. These dried samples were used for making the ash which was done with the aid of muffle furnace. The ash samples were digested in $1 \mathrm{~mL}$ concentrated nitric acid for $1 \mathrm{~h}$, after cooling 16 $\mathrm{mL}$ of $5 \%$ nitric acid was added to make a final volume of $17 \mathrm{~mL}$. This solution was then directly aspirated to atomic absorption and ICP spectrophotometer. The results obtained in ppm were calculated statistically.

For the estimation of isotopic ratios of carbon and nitrogen the cleaned and acid washed bones were selected and collagen of every sample was extracted. The required carbon-containing components were separated for every sample which was combusted on line carbonate system of ratio recording. Mass Spectrometer to obtain the required $\mathrm{CO}_{2}$. The liberated $\mathrm{CO}_{2}$ was automatically fed to the dual beam isotope-ratio mass spectrometer. For Carbon the internationally recognized standard PDB (pee dee belemnite) carbonates, a marine carbonate. For Nitrogen, the sample ratio is reported relative to AIR (ambient inhalable reservoir), which became the internationally recognized standard following the demonstration that the isotope ratio of $\mathrm{N}_{2}$ in the atmosphere is constant across the Globe $[6,16]$. Isotopic ratios of Carbon and Nitrogen which presented as delta $(\delta)$ values in parts per thousand ("per $\mathrm{mL}$ " represented by the symbol \%o) as shown in the following formulas $[17,18]$.

$$
\begin{aligned}
\delta^{13} \mathrm{C} & =\frac{{ }^{13} \mathrm{C} /{ }^{12} \mathrm{C}_{\text {Sample }}}{{ }^{13} \mathrm{C} /{ }^{12} \mathrm{C}_{\text {PDB Satndard }}}-1 \\
\delta^{15} \mathrm{~N} & =\frac{{ }^{15} \mathrm{~N} /{ }^{14} \mathrm{~N}_{\text {Sample }}}{{ }^{15} \mathrm{~N} /{ }^{14} \mathrm{~N}_{\text {AIR Satndard }}}-1
\end{aligned}
$$

The values obtained from the aforesaid equations are multiplied by 1,000 to get the exact value of each sample.

To know the information about the nature of the 
soil around the faunal remains, values of $\mathrm{pH}$ (hydrogen ion concentration) were also estimated at different locations of Roopkund Lake by using field $\mathrm{pH}$ meter. These values of soil $\mathrm{pH}$ are helpful for establishing the preservation status of faunal remains and archaeological artifacts as well. But in case of present study faunal remains selected for the analysis were also examined through ocular microscope and hand lances see the post depositional changes in the morphology of bones.

\section{Results and Discussion}

As the main aim of the present study was to know about the preservation status of archaeological faunal remains recovered from Roopkund Lake as well as reconstruction of dietary behaviour of the people buried in the Roopkund lake around 9th Century A.D. The results obtained from elemental analysis are presented in Tables 1 and 2, while isotope ratios of Carbon and Nitrogen estimated from 20 bone samples are shown in Table 3. At the same time, it is also clarified that for checking the preservation status of faunal remains, the estimated hydrogen ion concentration of soil at different locations are mentioned in Table 4.

However, before discussing the analytical results it is also important to note that trace element analysis and estimation of isotopic ratios of Carbon and Nitrogen have a great potential and significant feature to reconstruct the palaeodiet and past history of ancient animal population [19-24]. It is also well known that the archaeological remains in any archaeological sites are well preserved when environmental condition

Table 1 Mean values of concentration of different elements in the humorous bones of human remains from Roopkund Lake.

\begin{tabular}{|c|c|c|c|c|c|c|}
\hline \multirow{2}{*}{ Bones of } & & \multicolumn{5}{|c|}{ Concentration of elements (in ppm \pm S.D.) } \\
\hline & & $\mathrm{Ca}$ & $\mathrm{Sr}$ & $\mathrm{Ba}$ & $\mathrm{Mg}$ & $\mathrm{Zn}$ \\
\hline \multirow{2}{*}{ Sample } & \multirow{2}{*}{ No. 01} & $43,975.30$ & 388.22 & 302.52 & $6,265.22$ & 396.02 \\
\hline & & \pm 134.60 & \pm 20.55 & \pm 21.31 & \pm 15.25 & \pm 10.3 \\
\hline \multirow{2}{*}{ Sample } & \multirow{2}{*}{ No. 02} & $41,527.50$ & 372.25 & 284.75 & 2950.25 & 234.05 \\
\hline & & \pm 140.4 & \pm 18.52 & \pm 22.25 & \pm 13.50 & \pm 11.5 \\
\hline \multirow{2}{*}{ Sample } & \multirow{2}{*}{ No. 03} & $42,572.50$ & 367.50 & 286.55 & $2,980.25$ & 228.09 \\
\hline & & \pm 125.65 & \pm 15.35 & \pm 20.15 & \pm 15.75 & \pm 09.5 \\
\hline \multirow{2}{*}{ Sample } & \multirow{2}{*}{ No. 04} & $42,570.45$ & 385.56 & 314.52 & $6,904.50$ & 388.07 \\
\hline & & \pm 133.55 & \pm 18.57 & \pm 25.30 & \pm 16.25 & \pm 12.8 \\
\hline \multirow{2}{*}{ Sample } & \multirow{2}{*}{ No. 05} & $39,566.22$ & 372.25 & 290.72 & $2,955.75$ & 295.06 \\
\hline & & \pm 119.15 & \pm 20.55 & \pm 23.33 & \pm 113.25 & \pm 10.7 \\
\hline \multirow{2}{*}{ Sample } & \multirow{2}{*}{ No. 06} & $41,525.25$ & 382.58 & 316.45 & $6,775.25$ & 335.08 \\
\hline & & \pm 144.6 & \pm 10.77 & \pm 22.32 & \pm 18.55 & \pm 11.4 \\
\hline \multirow{2}{*}{ Sample } & \multirow{2}{*}{ No. 07} & $40,577.50$ & 369.52 & 285.44 & $2,925.25$ & 219.09 \\
\hline & & \pm 110.43 & \pm 19.55 & \pm 19.24 & \pm 113.25 & \pm 12.8 \\
\hline \multirow{2}{*}{ Sample } & \multirow{2}{*}{ No. 08} & $39,555.56$ & 375.58 & 287.60 & $2,805.25$ & 216.03 \\
\hline & & \pm 112.34 & \pm 17.50 & \pm 20.10 & \pm 23.25 & \pm 11.2 \\
\hline \multirow{2}{*}{ Sample } & \multirow{2}{*}{ No. 09} & $40,755.45$ & 368.75 & 278.58 & $2,895.25$ & 222.06 \\
\hline & & \pm 117.62 & \pm 16.33 & \pm 21.32 & \pm 22.25 & \pm 10.5 \\
\hline \multirow{2}{*}{ Sample } & \multirow{2}{*}{ No. 10} & $42,650.50$ & 373.53 & 315.75 & $6,795.25$ & 357.05 \\
\hline & & \pm 111.44 & \pm 19.25 & \pm 25.30 & \pm 32.25 & \pm 11.7 \\
\hline \multirow{2}{*}{\multicolumn{2}{|c|}{ Coastal herbivore }} & $37,954.67$ & 565.20 & 68.65 & $2,553.64$ & 89.22 \\
\hline & & \pm 13.50 & \pm 9.50 & \pm 5.50 & \pm 22.25 & \pm 5.11 \\
\hline \multirow{2}{*}{\multicolumn{2}{|c|}{ Terrestrial omnivore }} & $36,758.00$ & 367.10 & 237.75 & $5,937.00$ & 218.55 \\
\hline & & \pm 12.55 & \pm 5.50 & \pm 19.25 & \pm 32.54 & \pm 10.5 \\
\hline \multirow{2}{*}{\multicolumn{2}{|c|}{ Carnivore }} & $46,557.28$ & 278.54 & 366.50 & $7,535.50$ & 415.65 \\
\hline & & \pm 24.55 & \pm 10.42 & \pm 27.65 & \pm 1.45 & \pm 10.2 \\
\hline
\end{tabular}


Study of Preservation Status and Dietary Reconstruction in the Human Remains Recovered from Roopkund Lake through Chemical Analysis of Faunal Remains

Table 2 Mean values of concentration of different elements in the femur bones of human remains from Roopkund Lake.

\begin{tabular}{|c|c|c|c|c|c|c|}
\hline \multirow{2}{*}{ Bones of } & & \multicolumn{5}{|c|}{ Concentration of elements (in ppm \pm S.D.) } \\
\hline & & $\mathrm{Ca}$ & $\mathrm{Sr}$ & $\mathrm{Ba}$ & $\mathrm{Mg}$ & $\mathrm{Zn}$ \\
\hline \multirow{2}{*}{ Sample } & \multirow{2}{*}{ No. 11} & $41,533.53$ & 375.55 & 323.53 & $2,955.55$ & 231.02 \\
\hline & & \pm 99.62 & \pm 21.55 & \pm 29.32 & \pm 11.09 & \pm 10.4 \\
\hline \multirow{2}{*}{ Sample } & \multirow{2}{*}{ No. 12} & $42,752.55$ & 368.22 & 322.52 & $6,265.22$ & 396.02 \\
\hline & & \pm 101.62 & \pm 20.55 & \pm 18.36 & \pm 12.27 & \pm 10.3 \\
\hline \multirow{2}{*}{ Sample } & \multirow{2}{*}{ No. 13} & $40,768.82$ & 375.24 & 324.75 & $2,980.25$ & 228.09 \\
\hline & & \pm 111.53 & \pm 18.11 & \pm 15.23 & \pm 15.75 & \pm 09.5 \\
\hline \multirow{2}{*}{ Sample } & \multirow{2}{*}{ No. 14} & $40,572.50$ & 378.23 & 320.79 & $2,934.15$ & 295.33 \\
\hline & & \pm 127.54 & \pm 19.53 & \pm 19.24 & \pm 102.25 & \pm 10.2 \\
\hline \multirow{2}{*}{ Sample } & \multirow{2}{*}{ No. 15} & $43,656.75$ & 376.51 & 320.72 & $6,474.30$ & 328.09 \\
\hline & & \pm 122.16 & \pm 12.45 & \pm 15.05 & \pm 18.55 & \pm 19.4 \\
\hline \multirow{2}{*}{ Sample } & \multirow{2}{*}{ No. 16} & $40,865.55$ & 366.54 & 318.75 & $2,925.58$ & 199.03 \\
\hline & & \pm 144.44 & \pm 19.55 & \pm 12.22 & \pm 111.23 & \pm 15.8 \\
\hline \multirow{2}{*}{ Sample } & \multirow{2}{*}{ No. 17} & $41,577.52$ & 381.26 & 318.57 & $6,965.58$ & 345.06 \\
\hline & & \pm 115.62 & \pm 20.55 & \pm 25.30 & \pm 16.25 & \pm 11.8 \\
\hline \multirow{2}{*}{ Sample } & \multirow{2}{*}{ No. 18} & $41,432.53$ & 362.55 & 326.43 & $2,868.56$ & 221.05 \\
\hline & & \pm 144.6 & \pm 20.55 & \pm 25.30 & \pm 23.25 & \pm 11.3 \\
\hline \multirow{2}{*}{ Sample } & \multirow{2}{*}{ No. 19} & $43,578.58$ & 328.28 & 324.75 & $6,795.25$ & 357.05 \\
\hline & & \pm 144.6 & \pm 18.55 & \pm 15.22 & \pm 25.33 & \pm 11.7 \\
\hline \multirow{2}{*}{ Sample } & \multirow{2}{*}{ No. 20} & $42,566.55$ & 372.58 & 326.85 & $2,895.25$ & 222.06 \\
\hline & & \pm 144.77 & \pm 19.55 & \pm 15.35 & \pm 22.25 & \pm 10.5 \\
\hline \multirow{2}{*}{\multicolumn{2}{|c|}{ Coastal herbivore }} & $37,954.67$ & 568.25 & 70.85 & $2,553.64$ & 89.22 \\
\hline & & \pm 13.50 & \pm 10.55 & \pm 5.50 & \pm 22.25 & \pm 5.11 \\
\hline \multirow{2}{*}{\multicolumn{2}{|c|}{ Terrestrial omnivore }} & $36,758.00$ & 369.15 & 238.95 & $5,937.00$ & 218.55 \\
\hline & & \pm 12.55 & \pm 5.75 & \pm 19.25 & \pm 32.54 & \pm 10.5 \\
\hline \multirow{2}{*}{\multicolumn{2}{|c|}{ Carnivore }} & $46,557.28$ & 280.55 & 364.25 & $7,535.50$ & 415.65 \\
\hline & & \pm 24.55 & \pm 11.45 & \pm 27.65 & \pm 1.45 & \pm 10.3 \\
\hline
\end{tabular}

Table 3 Isotopic ratios of carbon and nitrogen in the faunal remains recovered from Roopkund Lake.

\begin{tabular}{lll}
\hline Skeletal remains of & $\begin{array}{l}\text { Isotopic ratio of carbon } \\
\left(\text { Delta }{ }^{13} \text { C) in \%o }(\text { per } \mathrm{mL})\right.\end{array}$ & $\begin{array}{l}\text { Isotopic ratio of nitrogen } \\
\left(\text { Delta }{ }^{15} \text { ) in \%o (per } \mathrm{mL}\right)\end{array}$ \\
\hline Sample No. 01 & -22.75 & 09.25 \\
Sample No. 02 & -17.27 & 08.25 \\
Sample No. 03 & -18.78 & 07.25 \\
Sample No. 04 & -23.58 & 10.25 \\
Sample No. 05 & -16.75 & 07.25 \\
Sample No. 06 & -25.65 & 09.25 \\
Sample No. 07 & -19.25 & 07.25 \\
Sample No. 08 & -24.05 & 10.25 \\
Sample No. 09 & -18.82 & 08.25 \\
Sample No. 10 & -23.95 & 10.25 \\
Sample No. 11 & -18.34 & 08.25 \\
Sample No. 12 & -26.70 & 09.25 \\
Sample No. 13 & -17.65 & 08.25 \\
Sample No. 14 & -25.20 & 11.25 \\
Sample No. 15 & -24.29 & 09.25 \\
Sample No. 16 & -19.32 & 08.25 \\
Sample No. 17 & -26.65 & 10.25 \\
Sample No. 18 & -18.62 & 07.25 \\
Sample No. 19 & -25.33 & 10.25 \\
Sample No. 20 & -17.85 & 08.25 \\
\hline
\end{tabular}


Table 4 pH in soils from different locations of Roopkund Lake.

\begin{tabular}{ll}
\hline Locations & Hydrogen ion concentration $(\mathrm{pH})$ \\
\hline 0.5 Mts. depth & 6.02 \\
East of lake & 6.22 \\
West of lake & 6.33 \\
North of lake & 6.45 \\
South of lake & \\
1.0 Mts. depth & 6.72 \\
East of lake & 6.85 \\
West of lake & 6.75 \\
North of lake & 6.95 \\
South of lake & \\
\hline
\end{tabular}

Table $5 \quad \delta^{13} \mathrm{C}$ and $\delta^{15} \mathrm{~N}$ values in different types of diets.

\begin{tabular}{lll}
\hline Types of diet & $\delta^{13} \mathrm{C}(\%)$ & $\delta^{13} \mathrm{~N}(\%)$ \\
\hline C3 plants only & -26.6 & 5.5 \\
Meat from herbivore on C3 diets & -25.7 & 9.5 \\
C4 plants only & -12.6 & 6.5 \\
Meat from herbivore on C4 diets & -11.4 & 9.6 \\
Marine plankton only & -19.2 & 12.6 \\
Meat from marine herbivore & -18.7 & 15.5 \\
Meat from marine carnivore & -17.6 & 18.8 \\
\hline
\end{tabular}

becomes favourable and for the chemical analysis only well preserved archaeological remains are selected, because digenetic remains lost their original chemical composition [19]. Based on the same assumptions, in the first phase of the present study we have estimated the hydrogen ion concentration of soil at different locations of Roopkund lakes, as it has already been reported by so many workers that highly acidic and alkaline soil are responsible the degradation of organic archaeological artifacts [6, 11, 12, 19] and relatively less acidic and alkaline conditions of soil are the best preservative for the archaeological remains.

Results obtained from the examination of faunal remains of Roopkund lake indicated that majority of the faunal remains are well preserved, as no any digenetic effects has been noticed in any samples considered for analysis. This is simultaneously verified by the positive values of hydrogen ion concentration (Table 4) estimated from the soils of Roopkund, as it is ranging between 6.02-6.95, which is slightly acidic in nature and this condition of soil is suitable for the preservation of archaeological artifacts $[6,11,12,19]$.
It has also been confirmed from earlier analytical studies that continuous intake of terrestrial food reduce the concentration level of $\mathrm{Mg}, \mathrm{Sr}$ and $\mathrm{Zn}$ in the animal bones, while it increases the values of $\mathrm{Ba}$, but continuous intake of terrestrial food along with meat reversed the concentration values of these elements which is clearly shown in Tables 1 and $2[6,25,26]$. Earlier studies also described that plant tissue contain a greater amount of $\mathrm{Mg}$ as compared to animal flesh but concentration of $\mathrm{Mg}$ also records the relative amounts of vegetation and meat in the animal diet $[25,26]$. It is evident from the analysis of present results shown in Tables 1 and 2 that the values of concentration of $\mathrm{Mg}$, $\mathrm{Zn}$ and $\mathrm{Ba}$ are higher in the bones of Roopkund as compared to coastal reference samples, which indicate a high terrestrial component in their diet. Meanwhile, higher levels of $\mathrm{Mg}$ estimated from more than 50\% samples suggest the terrestrial and meat consumption nature of these peoples. A detailed analyses of bone sample from marine and terrestrial animals recovered from different archaeological sites, show a lower level of $\mathrm{Ba}$ in marine animals, while higher values of same elements in terrestrial animals $[8,9,25]$. 
Simultaneously $\mathrm{Zn}$ is also a useful element for distinguishing carnivores from herbivores [19], as $\mathrm{Zn}$ is more concentrated in flesh than in most plant foods. Therefore, carnivores generally have high concentration of $\mathrm{Zn}$ than herbivores. The concentration level of $\mathrm{Zn}$ obtained from the present study also indicates that the peoples of Roopkund were omnivore but most of them showing the greater percentage of meat in their diet (Tables 1 and 2).

For the further confirmation we have also carried out the estimation of isotopic ratios of Carbon and Nitrogen in the same faunal remains as these values are positively correlated to the diet of animals. The Carbon isotopic ratios of for coastal skeletons range between -14 and 16 per $\mathrm{mL}(\%)$, while inland skeletons range between $-17 \%$ and $-19 \%$ Von Endt and Ortnet, 1984. Marine foods represent the isotopic ratios of $-12 \%$ and $-18 \%$, while terrestrial foods (meat and plants) average about -25\%. Similarly isotopic ratios of Nitrogen are equally useful in dietary reconstruction. Previous studies on isotopic ratios of Nitrogen indicated that in herbivores ratios of delta $\mathrm{N}$ is $4 \%-7 \%$ and for carnivore these values are 7\%o-19\%o and for Arctic hunter delta $\mathrm{N}$ value would be above $20 \%$ (Table 5).

The estimated ratios of Carbon and Nitrogen from faunal remains of Roopkund (Table 3) clearly indicated that these people were well nourished with higher percentage of terrestrial diet along with meat in their diet, and more than fifty percent peoples in this group were having a higher percentage of meat and terrestrial diet in their diet as it is verified from elemental and isotopic data (Tables 1,2 and 3).

For the purpose of correlation $\delta^{13} \mathrm{C}$ and $\delta^{15} \mathrm{~N}$ Values in different types of diets are presented in Table 5.

\section{Conclusions}

Results obtained from the estimation of isotopic ratios of Carbon, Nitrogen and trace element analysis of faunal remains recovered from Roopkund Lake, Central Garhwal Himalaya revealed that the faunal remains of peoples buries around 9thcentury are well preserved and these peoples belongs to omnivore group with rich $\mathrm{C} 4$ and meat in their diet (Tables 1, 2 and 3). This clearly indicated that there were two groups of peoples in that journey.

\section{Acknowledgments}

Authors are grateful to Director Archaeometry Lab, University of Wisconsin, Madison, USA for analyzing the samples and also Head department of History and Archaeology HNB Garhwal University for providing laboratory facilities.

\section{References}

[1] Stephen, W., Goldberg, P., and Bar-Yosef, O. 1993. "Bone Preservation on Kebara Cave, Israel Using On-Site Fourier Transform Infrared." Journal of Archaeological Science 20: 613-627.

[2] De Niro, M. J., and Epstein, S. 1978. "Influence of Diet on the Distribution of Carbon Isotopes in Animals." Geochimica ET Cosmochimica Acta 42: 495-506.

[3] Binford, L. R. 1981. Bones: Ancient Men and Modern Myths. New York: Academic Press.

[4] Brain, C. K. 1981. The Hunters on the Hunted: An Introduction to African Cave Taphonomy. Chicago, IL: University of Chicago Press.

[5] Klein R. G., and Cruz-Uribe, K. 1984. The Analysis of Animal Bones from Archaeological Sites. Chicago: University of Chicago Press, 1-266.

[6] Antoine, S. E., Pollard, A. M., Dresser, P. Q., and Whittle, A. W. R. 1988. "Bone Chemistry and Dietary Reconstruction in Prehistoric Britain: Examples from Orkney, Scotland." Proceedings of the 26th International Archaeometry Symposium, 101-106.

[7] Borgognini, T. S. M. 1989. "Reconstruction of Mesolithic Diet Using Dental Micro-Wear and Trace Element Analysis.” BAR International Series, Oxford: B.A.R., 508 (1): 283-320.

[8] Burton, J. H., and Price, T. D. 1991. "Palaeodietary Applications of Barium Values in Bone." Proceedings of the 27th International Symposium on Archaeometry, 787-795.

[9] Burton, J. H. 1996. "Trace Elements in Bone as Palaeodietary Indicators." Archaeological Chemistry 625:327-333.

[10] Chisholm, B. S., Nelson, D. E., and Schwarcz, H. 1982. "Stable Carbon Isotopes as a Measure of Marine versus Terrestrial Protein in Ancient Diets." Science 216:1131-1132. 
[11] Farswan, Y. S., and Nautiyal, V. 1997. "Trace Element Analysis of Archaeo-Faunal Remains of Garhwal Himalaya through I.C.P. Spectrometry." In Khanduri, B.M. and Nautiyal, V. Eds. Himkanti, New Delhi: Indian Publishing Company, 227-239.

[12] Nautiyal, V., Farswan, Y. S., and Uniyal, A. K. 1995. "Stable Carbon Isotope Analysis of Archaeological Bone from Garhwal Himalaya." Science and Culture 61 (7-9): 139-140.

[13] Price, T. D., Schoeninger, M. J., and Armilagos, G. J. 1985. "Bone Chemistry and Past Behaviour: an Overview." Journal of Human Evolution 14: 419-447.

[14] Price, T. D., Swick, R., and Chase, E. P. 1986. "Bone Chemistry and Prehistoric Diet: Strontium Studies of Laboratory Rats." American Journal of Physical Anthropology 70:365-375.

[15] Lambert, J. B., and Weydert-Homeyer, J. M. 1993. "The Fundamental Relationship between Ancient Diet and the Inorganic Constituents of Bone as Derived from Feeding Experiments.” Archaeometry 35 (2): 279-29.

[16] Mariotti, A. 1983. "Atmospheric Nitrogen is a Reliable Standard for Natural ${ }^{15} \mathrm{~N}$ Abundance Measurements." Nature 303: 685-687.

[17] Schoeninger, M. J., and Moore, K. 1992. "Bone Stable Isotope Studies in Archaeology." Journal of World Prehistory 6 (2): 247-296.

[18] Van Der Merwe, N. J. 1992. "Light Stable Isotopes and the Reconstruction of Prehistoric Diet." Proceedings of the British Academy 77: 247-26.

[19] Farswan, Y. S., and Price, T. D. 2002. "Reconstruction of Palaeodiet through Trace Element Analysis of Archaeological Faunal Remains." Indian Journal of
Environment and Ecoplanning 6 (2): 197-208.

[20] Thompson, A. H., Richards, M. P., Andrew S., and Zakrzewski, S. R. 2005. "Isotopic Palaeodiet Studies of Ancient Egyptian Fauna and Humans." Journal of Archaeological science 32 (3): 451-463.

[21] Bocherens, H., Polet, C., and Toussaint, M. 2007. "Palaeodiet of Mesolithic and Neolithic Populations of Meuse Basin (Belgium): Evidence from Stable Isotopes" Journal of Archaeological Science 34 (1): 10-27.

[22] Iacumi, N. P., Davanzo, S., and Nikolae, V. 2006. "Spatial and Temporal Variations in the ${ }^{13} \mathrm{C} /{ }^{12} \mathrm{C}$ and ${ }^{15} \mathrm{~N} /{ }^{14} \mathrm{~N}$ Ratios of Mammoth Hairs: Palaeodiet and Palaeoclimatic Implications." Chemical Geology, 231 (1-2): 16-25.

[23] Hollund, H. I., Higham, T., Belinskij, A., and Korenevskij, S. 2010. "Investigation of Palaeodiet in the North Caucasus (South Russia) Bronze Age Using Stable Isotope Analysis and AMS Dating of Human and Animal Bones." Journal of Archaeological Science 37 (12): 2971-2983.

[24] Al-Bashaireh, K., and Al-Muheisen Z. 2011. "Subsistence Strategies and Palaeodiet of Tell Al-Husn, Northern Jordan: Nitrogen and Carbon Stable Isotope Evidence and Radiocarbon Dates." Journal of Archaeological Science 38 (10): 2606-2612.

[25] Pate, F. D., and Hutton, J. T. 1987. "Bone Sr, Ba and Mg Variability in Marine and Terrestrial Mammals from the Adelaide Region, South Australia." Unpublished Manuscript.

[26] Pate, F. D. 1994. "Bone Chemistry and Palaeodiet." Journal of Archaeological Method and Theory 1 (2): 161-09. 